\title{
Pathogenicity of Rice Blast (Pyricularia oryzae Cavara) Isolates from Cambodia
}

\author{
Yoshimichi FUKUTA ${ }^{1,6 *}$, Ikumi KOGA ${ }^{1 *}$, Tochi UNG ${ }^{2}$, Khay SATHYA ${ }^{2}$, \\ Akiko KAWASAKI-TANAKA ${ }^{3,1}$, Yohei KOIDE ${ }^{1}$, Nobuya KOBAYASHI ${ }^{4}$, \\ Mitsuhiro OBARA ${ }^{1}$, Hun YADANA ${ }^{2}$ and Nagao HAYASHI \\ ${ }^{1}$ Japan International Research Center for Agricultural Sciences (Tsukuba, Ibaraki 305-8686, Japan) \\ ${ }^{2}$ Cambodian Agricultural Research and Development Institute (Sangkat Prateah Lang, Khan Dangkor, \\ Phnom Penh, Kingdom of Cambodia) \\ ${ }^{3}$ Tottori University (Tottori, Tottori 680-8553, Japan) \\ ${ }^{4}$ National Institute of Crop Science (Tsukuba, Ibaraki 305-8602, Japan) \\ ${ }^{5}$ National Institute of Agrobiological Sciences (Tsukuba, Ibaraki 305-8602, Japan)
}

\begin{abstract}
The evaluation of a total of 122 blast (Pyricularia oryzae Cavara) isolates collected from the Tonle Sap and Mekong river regions of Cambodia revealed wide variation. Using a new designation system, the blast isolates were categorized into 92 races based on the reaction patterns of rice (Oryza sativa L.) differential varieties (DVs) harboring 23 resistance genes and of 1 susceptible cultivar, Lijiangxintuanheigu (LTH). Cluster analysis was used to classify the blast isolates into 3 groups - I, IIa, and IIb - using data from these reaction patterns of the DVs and LTH. We used the classifications established under the new designation system, alongside cluster analysis and the geographical distribution of blast isolates, to investigate the diversity and differentiation of blast races in the Tonle Sap and Mekong river regions. The distributions of the blast races differed between the 2 regions, although blast isolates of group IIa were distributed commonly in both regions and groups I and IIb occurred at higher frequencies in the Tonle Sap region rather than the Mekong region. The blast isolates in groups I and IIb were also less diverse than those in group IIa. Accordingly, Group II blast isolates overall were distributed in both regions with high diversity, but some modified blast isolates were additionally distributed in the Tonle Sap region. We also investigated the pathogenicities of blast isolates from wild rice (Oryza rufipogon Griff) weeds neighboring the cultivated rice, and discuss the relationship between these isolates and those from cultivated rice.
\end{abstract}

Discipline: Plant disease

Additional key words: cluster analysis, differential variety, diversity, pathotype, resistance gene

\section{Introduction}

Rice blast, caused by the pathogen Pyricularia oryzae Cavara is one of the most significant diseases affecting rice worldwide ${ }^{22}$. The use of resistant cultivars is the most practical and economical method to control this blast disease in rice (Oryza sativa L.). However, using such varieties has limited effect owing to the breakdown of resistance genes, with more and more blast races overcoming resistance in rice $^{7}$. The dynamic interaction between host resistance and fungus virulence in rice blast pathosystems can be explained by the gene-for-gene theory: every resistance gene in the host corresponds to an avirulence gene in the pathogen ${ }^{2,15}$. Based on this theory, differential varieties (DVs), which can be used to distinguish pathotypes (races) by their reaction patterns to each pathogen strain, have been developed to identify the blast pathogen population structure and predict

This paper reports the results obtained in the JIRCAS research projects "Blast Network for Stable Rice Production" from 2006 to 2010 and "Rice Innovation for Environmentally Sustainable Production Systems" from 2011 to 2015

Present address:

${ }^{6}$ Tropical Agricultural Research Front, Japan International Research Center for Agricultural Sciences (Ishigaki, Okinawa 907-0002, Japan)

*Corresponding author: e-mail zen@affrc.go.jp

*These persons contributed equally to this work.

Received 25 March 2013; accepted 14 August 2013. 
the emergence of new blast races.

Using several sets of DVs, pathogenicity studies of blast isolates have been performed in China and Southeast Asia. Using 12 Japanese differential varieties (DVs) (for Pia, Pik-s, Pii, Pik, Pik-m, Piz, Pita, Pita-2, Piz-t, Pik-p, Pib and $P$ it) developed by Yamada et al. ${ }^{21}$, Kiyosawa ${ }^{8,9}$, and Kiyosawa et al. ${ }^{11}$, Noda et al. ${ }^{14}$ identified 12 kinds of blast race among 129 isolates collected from all over the Mekong river Delta area of Vietnam. Mekwatanakarn et al. ${ }^{13}$ then investigated the pathogenicities of 527 blast isolates from Thailand using, as DVs, CO 39 near-isogenic lines (NILs) for Pi1, Pi1-LAC(t), Pi1-TTP(t), Piz-5, Pi3, Pi4a, Pi4b(t) (Pita), Pi4a-PKT(t), Pi4a-TTP(t) and Pia and Lijiangxintuanheigu (LTH) NILs for Pik-m, Pita, Pita-2, Pib, Pik-p and Pik. They classified the isolates into 175 races. In Bhutan, 110 isolates were differentiated into 53 races based on the reactions of CO 39 NILs for Pi4b (Pita), Pi2 (Piz-5), Pi3, Pi4a (Pita), and Pil and LTH NILs for Pita, Pib, Pita-2, Pik-m and Pik- $p^{19}$. In China, 792 isolates were classified into 344 races using LTH NILs for Pita-2, Pib, Pik, Pik-m, Pita, and Pik-p and CO 39 NILs for Pita, Piz-5, Pi3 and Pi1 ${ }^{1}$. The pathogenicities of 119 blast isolates collected from the Philippines were characterized by Yamada et al. ${ }^{21}$, Kiyosawa ${ }^{8,9}$, and Kiyosawa et al. ${ }^{10}$ using 18 Japanese DVs (for Pia, Pib, Pii, Pit, Pita, Pish, Piz-t, Pi3, Piz-5, Pik, Pik-h, Pik-m, Pik-p, Pik-s, Pita-2, Piz, Pil and $P i 20(\mathrm{t}))$; the isolates were categorized into 70 races $^{17}$. In these previous studies, the use of different numbers and kinds of DVs hindered comparison of the results. However, the results indicate that DVs in each study can be used to explain wide variations in pathotypes in the blast populations of Southeast Asia and China and demonstrate the differential capacities of the pathogens. However, there has been no research into blast races in Cambodia, nor has any information on blast disease or genotypes of rice varieties there been collected.

To establish a durable system to protect against blast disease, since 2006 the Japan International Research Center for Agricultural Sciences (JIRCAS) has been conducting a collaborative study, "Blast Research Network for Stable Rice Production," targeting Southeast and East Asia. This international collaborative research aims to develop a differential system that can identify the pathogenicities of blast fungi and genotypes of resistance genes in rice varieties based on the gene-for-gene theory. The differential system comprises matrix data for the reactions between DVs and standard differential blast isolates. Twenty-five monogenenic lines harboring 23 resistance genes, namely Pish, Pib, Pit, Pia, Pii, Pi3, Pi5(t), Pik-s, Pik-m, Pil, Pik-h, Pik, Pik-p, Pi7(t), Pi9, Piz, Piz-5, Piz-t, Pita-2, Pita, Pi12(t), Pi19(t) or $P i 20(\mathrm{t})$, were developed as a new set of international DVs by several backcrosses using the Chinese susceptible rice variety $\mathrm{LTH}^{20}$, and a set of LTH NILs carrying 11 resistance genes (Pib, Piz-5, Pi9, Pi3, Pia, Pik-s, Pik, Pik-h, Pi7(t), Pita or Pita-2) developed by Telebanco-Yanoria et al. ${ }^{18}$. These DVs had the common genetic background of LTH, meaning the influence of genetic background on the appearance of blast symptoms was minimized. The targets of the DV sets and other useful materials released are major blast resistance genes, which have been used internationally as part of JIRCAS's research. These monogeneic lines and LTH NILs are being used to develop differential systems in each country through 1) pathogenicity analysis of blast isolates; 2) elucidation of blast race distribution; and 3) selection of standard differential blast isolates.

As a first step in developing a differential system for Cambodia, to clarify the distribution and differentiation of blast races we used the above-mentioned DVs to elucidate the pathogenicities of blast isolates collected from that country. Wild rice (Oryza rufipogon Griff) has always been conserved as a neighboring weed of cultivated rice in Cambodia, and we observed its infection with blast disease on our research trips. However, little information is available on the pathogenicity of blast races in wild rice and their interrelationships in O. rufipogon and O. sativa. We therefore investigated isolates collected from $O$. rufipogon as part of our preliminary research.

\section{Materials and Methods}

\section{Differential varieties}

As a set of DVs, we used 23 monogenic lines ${ }^{6,20}$ carrying 21 resistance genes (IRBLsh-B for Pish, IRBLt-K59 for Pit, IRBLb-B for Pib, IRBLa-A for Pia, IRBLi-F5 for Pii, IRBL3-CP4 for Pi3, IRBL5-M for Pi5(t), IRBLks-F5 for Pik-s, IRBLkm-Ts for Pik-m, IRBL1-CL for Pi1, IRBLkpK60 for Pik- $p$, IRBL7-M for Pi7(t), IRBL9-W for Pi9, IRBLz-Fu for $P i z$, IRBLz5-CA for Piz-5, IRBLzt-T for Piz$t$, IRBLta2-Re and IRBLta2-Pi for Pita-2, IRBL12-M for Pi12(t), IRBLta-K1 and IRBLta-CP1 for Pita, IRB119-A for $P i 19(\mathrm{t})$ or IRBL20-IR24 for Pi20(t)) and 2 NILs (IRBLkhK3[LT] for $P i k-h$ or IRBLk-K[LT] for $P i k)$, using the Chinese Japonica-type susceptible variety $\mathrm{LTH}^{18}$ as a control, to evaluate the pathogenicities of blast isolates from Cambodia.

\section{Blast samples}

A total of 122 blast isolates were collected from 2 different areas of Cambodia, namely Tonle Sap (Western region; 97 blast isolates) and the Mekong river (Eastern region; 25 blast isolates), in December 2008 and March and October 2010. Of these, 112 were collected from cultivated rice (O. sativa L.) and 10 from wild rice (O. rufipogon Griff) (Table 1). Blast isolates from wild rice were collected from plants growing as weeds near cultivated rice. 


\section{Inoculation and evaluation}

The set of 25 DVs and LTH was sown in plastic trays $(9.3 \times 15.3 \times 2.5 \mathrm{~cm})$ with garden soil, with each tray containing 3 or 4 seeds of each variety. Two sets of DVs were prepared for pathogenicity testing, and the average scores of the 2 sets were used to indicate the degrees of infection.

Blast isolates were basically inoculated in accordance with the method of Hayashi et al. ${ }^{5}$. The spore concentration was standardized to $1 \times 10^{5}$ spores $/ \mathrm{ml}$. DVs were inoculated approximately 19 days after sowing (at about the 4 th or 5 th leaf stage) by spraying 15 to $20 \mathrm{ml}$ of spore suspension per tray with a fine atomizer, whereupon the degree of disease of each seedling was evaluated 7 days after inoculation. The reactions of DVs were categorized into six scoring types ( 0 to 5 ) and summarized whereby 0 to 2 was resistant (R) and 3 to 5 was susceptible (S). However, 2 DVs (IRBLsh-B for Pish and IRBLta2-Pi for Pita-2) were evaluated as 0 to 3 resistant (R) and 4 or 5 susceptible (S) and another DV, IRBL5-M for Pi5(t), was evaluated as 0 or 1 resistant $(\mathrm{R})$ and 2 to 5 susceptible $(\mathrm{S})$.

Virulent blast isolates were designated in accordance with a new international designation system by Hayashi and Fukuta $^{4}$ using LTH monogenic lines. The blast isolates were designated by the reaction patterns of LTH and the 25 monogenic lines targeting the 23 resistance genes. The lines were categorized into 5 groups: (U) LTH, IRBLa-A, IRBLsh-B, IRBLb-B, and IRBLt-K59 (Table 2); (i) 3 lines with the Pii locus on chromosome 9 (Table 3); (k) 7 lines with the Pik region on chromosome 11 (Table 4); (z) 4 lines with the Piz region on chromosome 6 (Table 5); and (ta) 7 lines with the Pita region on chromosome 12 (Table 6). We replaced the 2 monogenic lines used by Hayashi and Fukuta ${ }^{4}$ (namely IRBLkh-K3 and IRBLk-K) with 2 LTH NILs (IRBLkh-K3[LT] and IRBLka-K[LT], respectively). Each group consisted of 1 to 3 variety units, to each of which we allocated 3 DVs (genes). We applied codes 1, 2, and 4 to the susceptible reactions of each of the 3 respective varieties to the blast isolates. Using Gilmour's method ${ }^{3}$, blast races were designated by the combined sum of the codes representing the reactions of the 3 varieties in each unit. Isolates classified this way were designated as "pathotypes" within each variety unit and as "races" using the set of all 5 pathotypes.

\section{Classification of blast isolates by cluster analysis}

The reaction patterns of the $25 \mathrm{DV}$ s harboring the 23 kinds of resistance gene or LTH to the blast fungus were analyzed using Ward's hierarchal analysis and JMP7.0.2 software (SAS Institute Inc., Cary, NC, USA) for Windows.

The diversity of blast isolates in each cluster group was also calculated using Simpson's index method ${ }^{16}$.

\section{Results}

\section{Reaction of DVs}

We investigated the pathogenicity of a total of 122 blast isolates (112 from cultivated rice (O. sativa L.) and 10 from wild rice (O. rufupugon) using $25 \mathrm{DVs}$ and LTH (Table 1).

There were high frequencies $(>60 \%)$ of occurrence of blast isolates virulent to $6 \mathrm{DVs}$ (for Pib, Pit, Pia, Piz-t, $P i 19(\mathrm{t})$ and $P i 20(\mathrm{t}))$ and LTH. There were moderate frequencies (20 to 60\%) of isolates virulent to $8 \mathrm{DVs}$ (for $P i i$, Pi3, Pi5(t), Pik-s, Piz-5, Pi12(t) and Pita (2)). There were low frequencies $(<20 \%)$ of blast isolates virulent to the remaining $11 \mathrm{DVs}$ (for Pish, Pik-m, Pil, Pik-h, Pik, Pik-p, Pi7(t), Pi9(t), Piz and Pita-2 (2)) (Fig. 1). There were no blast isolates virulent to DVs for Pik- $h$. A total of 4 blast isolates $(3.3 \%)$ showed avirulence to LTH, suggesting that LTH harbored 1 or more resistance genes in its genetic background. However, these genes were estimated to be of minor importance, because no blast isolates compatible with LTH have been found in China ${ }^{11}$ and no major resistance genes have been identified in $\mathrm{LTH}^{20}$.

\section{Classification of blast isolates based on DV reaction patterns}

A total of 122 blast isolates were classified into 2 major groups (I and II) and then divided into subgroups (IIa and IIb) based on the reaction patterns of the DVs and LTH (Table 1, Fig. 1). A total of 38 blast isolates (31.1\%) were classified into group I, in which the frequencies of isolates virulent to $6 \mathrm{DVs}$ (for Pii, Pi3, Pi5(t), Pik-s, Pi12(t) and Pita(2)) were higher, and that of isolates virulent to $1 \mathrm{DV}$ (for Pi20(t)) was lower, than in group II.

The other 84 blast isolates $(68.9 \%)$ were classified into group II, with 48 (39.3\%) and 36 (29.5\%) isolates categorized into subgroups IIa and IIb, respectively. The blast isolates in subgroup IIb showed higher frequencies of virulence than those of subgroup IIa against 9 DVs (for Pib, Pit, Pia, Pi9, Piz, Piz-5, Piz-t, Pi19(t) and Pi20(t)).

Blast isolates from cultivated rice fell into all cluster groups, but those from wild rice (O. rufipogon Griff) fell into only 2 groups, namely I (6 isolates) and IIa (4 isolates). Five of the blast isolates from group I were found in the Tonle Sap region, and 1 isolate from group I and 4 isolates from group IIa were found in the Mekong river region.

The 97 blast isolates from Tonle Sap were divided into 3 cluster groups, I $(\mathrm{n}=36,29 . \%)$, IIa $(\mathrm{n}=29,23.8 \%)$ and IIb $(\mathrm{n}=32,26.2 \%)$ with similar frequencies. These frequencies differed among the 3 groups in the Mekong river region. Of the 25 blast isolates, 19 (15.6\%) were categorized into group IIa; in the Mekong region there were very few isolates in the other 2 groups (Table 1, Fig. 2). Blast isolates of group IIa were distributed widely in the Tonle 
Table 1. Numbers of blast isolates in each group from Cambodia

\begin{tabular}{|c|c|c|c|c|c|c|}
\hline \multirow[t]{3}{*}{ Region } & \multirow{3}{*}{$\begin{array}{l}\text { Cultivated }(\mathrm{Cv}) \\
\text { or wild rice }(\mathrm{W})\end{array}$} & \multicolumn{4}{|c|}{ No. of blast isolates (\%) } & \multirow[t]{3}{*}{ Total } \\
\hline & & \multirow{2}{*}{ I } & \multicolumn{3}{|c|}{ II } & \\
\hline & & & $\mathrm{a}$ & $\mathrm{b}$ & Sum & \\
\hline \multirow{3}{*}{ Tonle Sap } & $\mathrm{Cv}$ & $\begin{array}{c}31 \\
(25.4)\end{array}$ & $\begin{array}{c}29 \\
(23.8)\end{array}$ & $\begin{array}{c}32 \\
(26.2)\end{array}$ & $\begin{array}{c}61 \\
(50.0)\end{array}$ & $\begin{array}{c}92 \\
(75.4)\end{array}$ \\
\hline & W & $\begin{array}{c}5 \\
(4.1)\end{array}$ & $\begin{array}{c}0 \\
(0.0)\end{array}$ & $\begin{array}{c}0 \\
(0.0)\end{array}$ & $\begin{array}{c}0 \\
(0.0)\end{array}$ & $\begin{array}{c}5 \\
(4.1)\end{array}$ \\
\hline & SUM & $\begin{array}{c}36 \\
(29.5)\end{array}$ & $\begin{array}{c}29 \\
(23.8)\end{array}$ & $\begin{array}{c}32 \\
(26.2)\end{array}$ & $\begin{array}{c}61 \\
(50.0)\end{array}$ & $\begin{array}{c}97 \\
(79.5)\end{array}$ \\
\hline \multirow{3}{*}{ Mekong river } & $\mathrm{Cv}$ & $\begin{array}{c}1 \\
(0.8)\end{array}$ & $\begin{array}{c}15 \\
(12.3)\end{array}$ & $\begin{array}{c}4 \\
(3.3)\end{array}$ & $\begin{array}{c}19 \\
(15.6)\end{array}$ & $\begin{array}{c}20 \\
(16.4)\end{array}$ \\
\hline & W & $\begin{array}{c}1 \\
(0.8)\end{array}$ & $\begin{array}{c}4 \\
(3.3)\end{array}$ & $\begin{array}{c}0 \\
(0.0)\end{array}$ & $\begin{array}{c}4 \\
(3.3)\end{array}$ & $\begin{array}{c}5 \\
(4.1)\end{array}$ \\
\hline & SUM & $\begin{array}{c}2 \\
(1.6)\end{array}$ & $\begin{array}{c}19 \\
(15.6)\end{array}$ & $\begin{array}{c}4 \\
(3.3)\end{array}$ & $\begin{array}{c}23 \\
(18.9)\end{array}$ & $\begin{array}{c}25 \\
(20.5)\end{array}$ \\
\hline \multirow{2}{*}{ Subtotal } & $\mathrm{Cv}$ & $\begin{array}{c}32 \\
(26.2)\end{array}$ & $\begin{array}{c}44 \\
(36.1)\end{array}$ & $\begin{array}{c}36 \\
(29.5)\end{array}$ & $\begin{array}{c}80 \\
(65.6)\end{array}$ & $\begin{array}{c}112 \\
(91.8)\end{array}$ \\
\hline & W & $\begin{array}{c}6 \\
(4.9)\end{array}$ & $\begin{array}{c}4 \\
(3.3)\end{array}$ & $\begin{array}{c}0 \\
(0.0)\end{array}$ & $\begin{array}{c}4 \\
(3.3)\end{array}$ & $\begin{array}{c}10 \\
(8.2)\end{array}$ \\
\hline Total & & $\begin{array}{c}38 \\
(31.1)\end{array}$ & $\begin{array}{c}48 \\
(39.3) \\
\end{array}$ & $\begin{array}{c}36 \\
(29.5) \\
\end{array}$ & $\begin{array}{c}84 \\
(68.9) \\
\end{array}$ & $\begin{array}{c}122 \\
(100.0)\end{array}$ \\
\hline
\end{tabular}

Sampling was performed in two regions, Tonle Sap and the Mekong river, in December 2008 and March and October 2010.

The pathogenicities of a total of 122 blast isolates, including 10 from wild rice (Oryza rufipogon), were evaluated based on the reactions of a susceptible control (LTH) and 25 differential varieties targeting 23 resistance genes. Cluster analysis was performed using data on reaction patterns to the blast isolates.
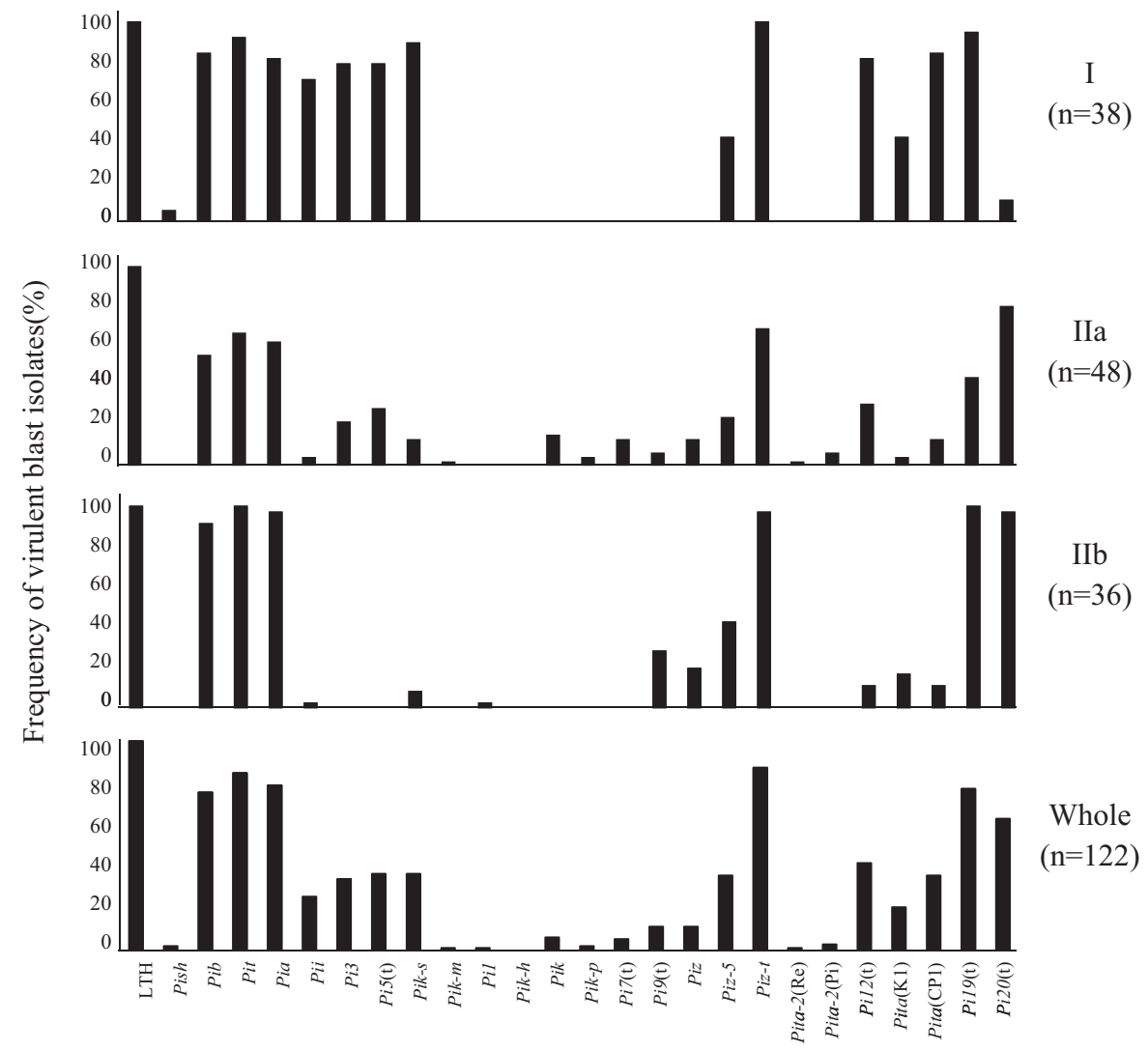

Susceptible variety, LTH, and resistance genes in differential varieties

Fig. 1. Frequencies of occurrence of Cambodian blast isolates virulent against differential varieties susceptible control, LTH 


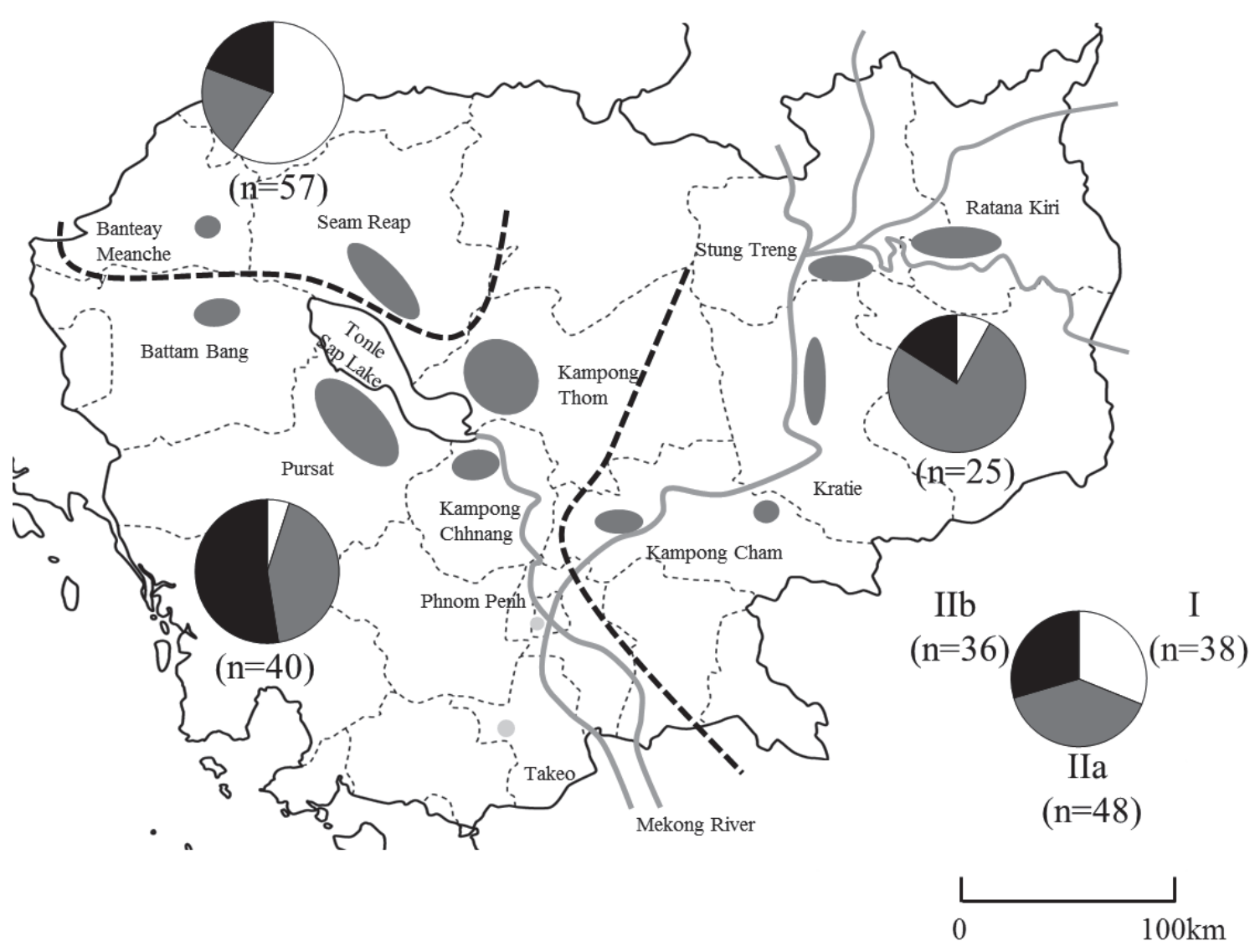

Fig. 2. Distribution of blast isolates classified into three groups; I, IIa and IIb, in Cambodia : Area for sampling

Sap and Mekong river regions, whereas those of groups I and IIb were limited mainly to the Tonle Sap region and those of group I were particularly common in Siem Reap Province, to the north of Tonle Sap.

The blast isolates from wild rice were classified into groups I $(6 ; 4.9 \%)$ and IIa (4; 3.3\%); none fell into group IIb. The 6 and 4 blast isolates of groups I and II were sampled in the provinces of Siem Reap and Stung Treng, and Ban Lung and Stung Treng, respectively, all of which were in northern Cambodia (data not shown).

\section{Pathotypes of blast isolates, based on DV reactions in the 5 variety groups}

(1) LTH and 4 DVs (for Pish, Pib, Pit and Pia) in group U

Among the 122 blast isolates, we found a total of 13 pathotypes (U00, U01, U03, U21, U23, U40, U41, U42, U43, U53, U61, U63 and U73) against LTH and 4 DVs (for Pish, Pib, Pit and Pia) in variety group U (Table 2). (Resistant $(\mathrm{R})$ and susceptible $(\mathrm{S})$ reactions are categorized as incompatible $(-)$ and compatible $(+)$, respectively, in the tables.) A total of 65 blast isolates $(53.3 \%)$ were categorized into pathotype $\mathrm{U} 63$, which was common in the 3 cluster groups, I, IIa and IIb. U43 and U61 included 13 and 12 blast isolates, respectively, and were found in all cluster groups. Each of the other pathotypes included fewer than 8 isolates (Table 2).

There were no significant differences in the numbers of blast isolates in the 13 pathotypes among the three cluster groups, but the kinds and numbers of pathotypes varied among the groups. There were 7,11 and 3 pathotypes in groups I, IIa and IIb, respectively. The overall diversity and those of the 3 cluster groups by Simpson's index (Simpson, 1949) were $0.69,0.62,0.88$ and 0.20 , respectively.

(2) Three DVs (for Pii, Pi3 and Pi5(t)) in group i

A total of 7 pathotypes (i0, i1, i2, i3, i4, i6 and i7) were found against variety group i. Pathotype i0 was dominant and included 69 blast isolates (56.6\%). The second most common was pathotype i7, which included 23 blast isolates $(18.9 \%)$. The other 5 pathotypes each had fewer than 12 blast isolates $(<10 \%)$ (Table 3$)$.

Among the 69 blast isolates of pathotype i0, 66 (54.1\%) were classified into cluster group II and only 3 fell into group I. In contrast, all 23 blast isolates (18.9\%) of pathotype 17 were found in group I, and none were contained in group II. Pathotypes i0 and i7 were thus differentiated by their respective occurrences in groups II and I. 
Table 2. Numbers of blast isolates in pathotypes against the differential variety group $\mathrm{U}$, corresponding to LTH and the resistance genes Pish, Pib, Pit and Pia, and the degrees of diversity in cluster groups

\begin{tabular}{|c|c|c|c|c|c|c|c|c|c|c|c|c|c|c|c|}
\hline \multirow{2}{*}{ Cluster group } & \multicolumn{14}{|c|}{ Number of blast isolates (\%) } & \multirow{6}{*}{ 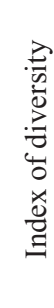 } \\
\hline & \multicolumn{14}{|c|}{ Pathotypes } & \\
\hline Resistance gene & U00 & U01 & U03 & $\mathrm{U} 21$ & $\mathrm{U} 23$ & $\mathrm{U} 40$ & U41 & U42 & U43 & U53 & U61 & U63 & U73 & \multirow{4}{*}{ 吾 } & \\
\hline$\underset{\Xi}{\mathbb{O}} \quad$ Pish $\mathrm{LTH}$ & -- & -+ & -+ & -+ & -+ & -- & -+ & -- & -+ & ++ & -+ & -+ & ++ & & \\
\hline Pib Pia & -- & -- & -+ & +- & ++ & -- & -- & -+ & -+ & -+ & +- & ++ & ++ & & \\
\hline$\simeq \quad$ Pit & -- & - & - & - & - & + & + & + & + & + & + & + & + & & \\
\hline I & $\begin{array}{c}0 \\
(0.0)\end{array}$ & $\begin{array}{c}0 \\
(0.0)\end{array}$ & $\begin{array}{c}0 \\
(0.0)\end{array}$ & $\begin{array}{c}1 \\
(0.8)\end{array}$ & $\begin{array}{c}2 \\
(1.6)\end{array}$ & $\begin{array}{c}0 \\
(0.0)\end{array}$ & $\begin{array}{c}0 \\
(0.0)\end{array}$ & $\begin{array}{c}0 \\
(0.0)\end{array}$ & $\begin{array}{c}5 \\
(4.1)\end{array}$ & $\begin{array}{c}1 \\
(0.8)\end{array}$ & $\begin{array}{c}6 \\
(4.9) \\
\end{array}$ & $\begin{array}{c}22 \\
(18.0)\end{array}$ & $\begin{array}{c}1 \\
(0.8)\end{array}$ & $\begin{array}{c}38 \\
(31.1)\end{array}$ & 0.62 \\
\hline \multirow{2}{*}{ II } & $\begin{array}{c}2 \\
(1.6)\end{array}$ & $\begin{array}{c}4 \\
(3.3)\end{array}$ & $\begin{array}{c}5 \\
(4.1)\end{array}$ & $\begin{array}{c}3 \\
(2.5)\end{array}$ & $\begin{array}{c}5 \\
(4.1)\end{array}$ & $\begin{array}{c}1 \\
(0.8)\end{array}$ & $\begin{array}{c}6 \\
(4.9)\end{array}$ & $\begin{array}{c}1 \\
(0.8)\end{array}$ & $\begin{array}{c}5 \\
(4.1)\end{array}$ & $\begin{array}{c}0 \\
(0.0)\end{array}$ & $\begin{array}{c}5 \\
(4.1)\end{array}$ & $\begin{array}{c}11 \\
(9.0)\end{array}$ & $\begin{array}{c}0 \\
(0.0)\end{array}$ & $\begin{array}{c}48 \\
(39.3)\end{array}$ & 0.88 \\
\hline & $\begin{array}{c}0 \\
(0.0)\end{array}$ & $\begin{array}{c}0 \\
(0.0)\end{array}$ & $\begin{array}{c}0 \\
(0.0)\end{array}$ & $\begin{array}{c}0 \\
(0.0)\end{array}$ & $\begin{array}{c}0 \\
(0.0)\end{array}$ & $\begin{array}{c}0 \\
(0.0)\end{array}$ & $\begin{array}{c}0 \\
(0.0)\end{array}$ & $\begin{array}{c}0 \\
(0.0)\end{array}$ & $\begin{array}{c}3 \\
(2.5)\end{array}$ & $\begin{array}{c}0 \\
(0.0)\end{array}$ & $\begin{array}{c}1 \\
(0.8)\end{array}$ & $\begin{array}{c}32 \\
(26.2)\end{array}$ & $\begin{array}{c}0 \\
(0.0)\end{array}$ & $\begin{array}{c}36 \\
(29.5)\end{array}$ & 0.20 \\
\hline Sum & $\begin{array}{c}2 \\
(1.6)\end{array}$ & $\begin{array}{c}4 \\
(3.3)\end{array}$ & $\begin{array}{c}5 \\
(4.1)\end{array}$ & $\begin{array}{c}3 \\
(2.5)\end{array}$ & $\begin{array}{c}5 \\
(4.1)\end{array}$ & $\begin{array}{c}1 \\
(0.8)\end{array}$ & $\begin{array}{c}6 \\
(4.9)\end{array}$ & $\begin{array}{c}1 \\
0.8\end{array}$ & $\begin{array}{c}8 \\
(6.6) \\
\end{array}$ & $\begin{array}{c}0 \\
(0.0)\end{array}$ & $\begin{array}{c}6 \\
(4.9)\end{array}$ & $\begin{array}{c}43 \\
(35.2)\end{array}$ & $\begin{array}{c}0 \\
(0.0)\end{array}$ & $\begin{array}{c}84 \\
(68.9)\end{array}$ & 0.71 \\
\hline Total & $\begin{array}{c}2 \\
(1.6) \\
\end{array}$ & $\begin{array}{c}4 \\
(3.3) \\
\end{array}$ & $\begin{array}{c}5 \\
(4.1) \\
\end{array}$ & $\begin{array}{c}4 \\
(3.3) \\
\end{array}$ & $\begin{array}{c}7 \\
(5.7) \\
\end{array}$ & $\begin{array}{c}1 \\
(0.8) \\
\end{array}$ & $\begin{array}{c}6 \\
(4.9) \\
\end{array}$ & $\begin{array}{c}1 \\
(0.8) \\
\end{array}$ & $\begin{array}{c}13 \\
(10.7) \\
\end{array}$ & $\begin{array}{c}1 \\
(0.8) \\
\end{array}$ & $\begin{array}{c}12 \\
(9.8) \\
\end{array}$ & $\begin{array}{c}65 \\
(53.3) \\
\end{array}$ & $\begin{array}{c}1 \\
(0.8) \\
\end{array}$ & $\begin{array}{c}122 \\
(100.0)\end{array}$ & 0.69 \\
\hline
\end{tabular}

Each pathotype was categorized in accordance with the method of Hayashi et al. (2009).

- : incompatibility reaction, + : compatibility reaction.

Indexes of diversity were calculated using the method of Simpson (1949).

Table 3. Numbers of blast isolates in pathotypes against differential variety group $i$, corresponding to resistance genes $P i i, P i 3$ and $P i 5(t)$, and the degrees of diversity in cluster groups

\begin{tabular}{|c|c|c|c|c|c|c|c|c|c|c|}
\hline \multirow{2}{*}{\multicolumn{2}{|c|}{ Cluster group }} & \multicolumn{7}{|c|}{ Number of blast isolates (\%) } & \multirow{6}{*}{ 吾 } & \multirow{6}{*}{ 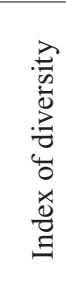 } \\
\hline & & \multicolumn{7}{|c|}{ Pathotypes } & & \\
\hline \multicolumn{2}{|c|}{ Resistance gene } & i0 & i1 & i2 & $\mathrm{i} 3$ & i4 & i6 & i7 & & \\
\hline \multirow{3}{*}{ 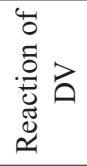 } & $P i i$ & - & + & - & + & - & - & + & & \\
\hline & $P i 3$ & - & - & + & + & - & + & + & & \\
\hline & $\operatorname{Pi5}(\mathrm{t})$ & - & - & - & - & + & + & + & & \\
\hline \multicolumn{2}{|r|}{ I } & $\begin{array}{c}3 \\
(2.5)\end{array}$ & $\begin{array}{c}1 \\
(0.8)\end{array}$ & $\begin{array}{c}1 \\
(0.8)\end{array}$ & $\begin{array}{c}3 \\
(2.5)\end{array}$ & $\begin{array}{c}4 \\
(3.3)\end{array}$ & $\begin{array}{c}3 \\
(2.5)\end{array}$ & $\begin{array}{c}23 \\
(18.9)\end{array}$ & $\begin{array}{c}38 \\
(31.1)\end{array}$ & 0.60 \\
\hline \multicolumn{2}{|c|}{ IIa } & $\begin{array}{c}31 \\
(25.4)\end{array}$ & $\begin{array}{c}2 \\
(1.6)\end{array}$ & $\begin{array}{c}2 \\
(1.6)\end{array}$ & $\begin{array}{c}0 \\
(0.0)\end{array}$ & $\begin{array}{c}5 \\
(4.1)\end{array}$ & $\begin{array}{c}8 \\
(6.6)\end{array}$ & $\begin{array}{c}0 \\
(0.0)\end{array}$ & $\begin{array}{c}48 \\
(39.3)\end{array}$ & 0.54 \\
\hline \multicolumn{2}{|c|}{$\mathrm{IIb}$} & $\begin{array}{c}35 \\
(28.7)\end{array}$ & $\begin{array}{c}1 \\
(0.8)\end{array}$ & $\begin{array}{c}1 \\
(0.8)\end{array}$ & $\begin{array}{c}0 \\
(0.0)\end{array}$ & $\begin{array}{c}0 \\
(0.0)\end{array}$ & $\begin{array}{c}0 \\
(0.0)\end{array}$ & $\begin{array}{c}0 \\
(0.0)\end{array}$ & $\begin{array}{c}36 \\
(29.5)\end{array}$ & 0.05 \\
\hline \multicolumn{2}{|c|}{ Sum } & $\begin{array}{c}66 \\
(54.1)\end{array}$ & $\begin{array}{c}3 \\
(2.5)\end{array}$ & $\begin{array}{c}2 \\
(1.6)\end{array}$ & $\begin{array}{c}0 \\
(0.0)\end{array}$ & $\begin{array}{c}5 \\
(4.1)\end{array}$ & $\begin{array}{c}8 \\
(6.6)\end{array}$ & $\begin{array}{c}0 \\
(0.0)\end{array}$ & $\begin{array}{c}84 \\
(68.9)\end{array}$ & 0.37 \\
\hline \multicolumn{2}{|c|}{ Total } & $\begin{array}{c}69 \\
(56.6)\end{array}$ & $\begin{array}{c}4 \\
(3.3)\end{array}$ & $\begin{array}{c}3 \\
(2.5)\end{array}$ & $\begin{array}{c}3 \\
(2.5)\end{array}$ & $\begin{array}{c}9 \\
(7.4)\end{array}$ & $\begin{array}{c}11 \\
(9.0)\end{array}$ & $\begin{array}{c}23 \\
(18.9)\end{array}$ & $\begin{array}{c}122 \\
(100.0)\end{array}$ & 0.63 \\
\hline
\end{tabular}

Each pathotype was categorized in accordance with the method of Hayashi et al. (2009).

- : incompatibility reaction, + : compatibility reaction.

Indexes of diversity were calculated using the method of Simpson (1949).

There were 7, 5 and 3 pathotypes in groups I, IIa and $\mathrm{IIb}$, respectively. The overall diversity and those of the 3 cluster groups I, IIa, and IIb were $0.63,0.60,0.54$ and 0.05 , respectively. The diversities therefore did not differ greatly between groups I and IIa, but that of group IIb was much lower.

(3) Seven DVs (for Pik-s, Pik-m, Pil, Pik-h, Pik, Pik-p and $\mathrm{Pi7}(\mathrm{t}))$ in group $\mathrm{k}$

A total of 8 pathotypes $(\mathrm{k} 000, \mathrm{k} 001, \mathrm{k} 002, \mathrm{k} 004, \mathrm{k} 005$, $\mathrm{k} 020, \mathrm{k} 100$ and k110) were found against variety group k 
Table 4. Numbers of blast isolates in pathotypes against differential variety group $k$, corresponding to resistance genes Pik-s, Pik-m, Pil, Pik-h,Pik,Pik-p and Pi7(t), and the degrees of diversity in cluster groups

\begin{tabular}{|c|c|c|c|c|c|c|c|c|c|c|c|c|c|}
\hline \multirow{2}{*}{\multicolumn{4}{|c|}{ Cluster group }} & \multicolumn{8}{|c|}{ Number of blast isolates (\%) } & \multirow{6}{*}{$\stackrel{\pi}{0}$} & \multirow{6}{*}{ 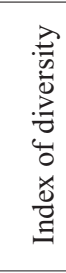 } \\
\hline & & & & \multicolumn{8}{|c|}{ Pathotypes } & & \\
\hline \multirow{4}{*}{ 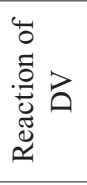 } & \multicolumn{3}{|c|}{ Resistance gene } & k000 & k001 & k002 & k004 & k005 & k020 & $\mathrm{k} 100$ & $\mathrm{k} 110$ & & \\
\hline & \multirow[t]{3}{*}{$P i k-s$} & Pik-m & $P i k$ & -- & --+ & -- & $-{ }_{-}$ & $-{ }_{-}^{+}$ & - - - & +- & ++ & & \\
\hline & & Pil & Pik-p & -- & - & -+ & -- & -- & +- & - - & -- & & \\
\hline & & Pik-h & $P i 7(\mathrm{t})$ & -- & -- & -- & -+ & -+ & -- & - & -- & & \\
\hline \multicolumn{4}{|c|}{ I } & $\begin{array}{c}4 \\
(3.3)\end{array}$ & $\begin{array}{c}0 \\
(0.0)\end{array}$ & $\begin{array}{c}0 \\
(0.0)\end{array}$ & $\begin{array}{c}0 \\
(0.0)\end{array}$ & $\begin{array}{c}0 \\
(0.0)\end{array}$ & $\begin{array}{c}0 \\
(0.0)\end{array}$ & $\begin{array}{c}34 \\
(27.9)\end{array}$ & $\begin{array}{c}0 \\
(0.0)\end{array}$ & $\begin{array}{c}38 \\
(31.1)\end{array}$ & 0.19 \\
\hline \multicolumn{4}{|c|}{ IIa } & $\begin{array}{c}32 \\
(26.2)\end{array}$ & $\begin{array}{c}2 \\
(1.6)\end{array}$ & $\begin{array}{c}2 \\
(1.6)\end{array}$ & $\begin{array}{c}1 \\
(0.8)\end{array}$ & $\begin{array}{c}5 \\
(4.1)\end{array}$ & $\begin{array}{c}0 \\
(0.0)\end{array}$ & $\begin{array}{c}5 \\
(4.1)\end{array}$ & $\begin{array}{c}1 \\
(0.8)\end{array}$ & $\begin{array}{c}48 \\
(39.3)\end{array}$ & 0.53 \\
\hline \multicolumn{4}{|c|}{$\mathrm{IIb}$} & $\begin{array}{c}32 \\
(26.2)\end{array}$ & $\begin{array}{c}0 \\
(0.0)\end{array}$ & $\begin{array}{c}0 \\
(0.0)\end{array}$ & $\begin{array}{c}0 \\
(0.0)\end{array}$ & $\begin{array}{c}0 \\
(0.0)\end{array}$ & $\begin{array}{c}1 \\
(0.8)\end{array}$ & $\begin{array}{c}3 \\
(2.5)\end{array}$ & $\begin{array}{c}0 \\
(0.0)\end{array}$ & $\begin{array}{c}36 \\
(29.5)\end{array}$ & 0.20 \\
\hline \multicolumn{4}{|c|}{ Sum } & $\begin{array}{c}64 \\
(52.5)\end{array}$ & $\begin{array}{c}2 \\
(1.6)\end{array}$ & $\begin{array}{c}2 \\
(1.6)\end{array}$ & $\begin{array}{c}1 \\
(0.8)\end{array}$ & $\begin{array}{c}5 \\
(4.1)\end{array}$ & $\begin{array}{c}1 \\
(0.8)\end{array}$ & $\begin{array}{c}8 \\
(6.6)\end{array}$ & $\begin{array}{c}1 \\
(0.8)\end{array}$ & $\begin{array}{c}84 \\
(68.9)\end{array}$ & 0.41 \\
\hline \multicolumn{4}{|c|}{ Total } & $\begin{array}{c}68 \\
(55.7)\end{array}$ & $\begin{array}{c}2 \\
(1.6)\end{array}$ & $\begin{array}{c}2 \\
(1.6) \\
\end{array}$ & $\begin{array}{c}1 \\
(0.8) \\
\end{array}$ & $\begin{array}{c}5 \\
(4.1) \\
\end{array}$ & $\begin{array}{c}1 \\
(0.8) \\
\end{array}$ & $\begin{array}{c}42 \\
(34.4) \\
\end{array}$ & $\begin{array}{c}1 \\
(0.8) \\
\end{array}$ & $\begin{array}{c}122 \\
(100.0)\end{array}$ & 0.57 \\
\hline
\end{tabular}

Each pathotype was categorized in accordance with the method of Hayashi et al. (2009).

- : incompatibility reaction, + : compatibility reaction.

Indexes of diversity were calculated using the method of Simpson (1949).

(Table 4). k000 included 68 blast isolates (55.7\%). Only 4 blast isolates were classified into cluster group I; the other 64 were categorized into group II. In contrast, k100 had 42 blast isolates (34.4\%); 34 and 8 were categorized into groups I and II, respectively. The other 6 pathotypes each included fewer than 6 blast isolates $(<5 \%)$ (Table 4$)$. These results indicated that there were 2 dominant pathotypes, k000 and k100, and 6 minor pathotypes. The 2 dominant pathotypes could be differentiated by the differences in their distributions between cluster groups I and II - in other words, by the reaction of DVs carrying Pik-s.

Groups I, IIa, and IIb included 2, 7 and 3 pathotypes, respectively. The overall diversity and those of the 3 cluster groups I, IIa, and IIb were 0.57, 0.19, 0.53 and 0.20, respectively; group IIa therefore had the highest diversity.

(4) Four DVs (for, Pi9(t), Piz, Piz-5 and Piz-t) in group z

A total of 11 pathotypes (z00, z01, z02, z04, z05, z06, z07, z13, z14, z16 and z17) were found against variety group z. A total of 56 blast isolates $(45.9 \%)$ were categorized into z04; in groups I, IIa, and IIb there were 22 (18.0\%), $19(15.6 \%)$ and $15(12.3 \%)$ blast isolates, respectively. z04 was dominant in all groups. A total of 14 $(11.5 \%)$ and $26(21.3 \%)$ blast isolates were categorized into z00 and z06, respectively. Group I had no z00 blast isolates, while group IIa had a greater number of isolates $(13 ; 10.7 \%)$ than group IIb $(1 ; 0.8 \%)$. In z06, there were $16(13.1 \%)$ isolates in group I and only $10(8.2 \%)$ in group II. Each of the other 8 pathotypes contained fewer than 7 blast isolates $(<5 \%)$ (Table 5). The numbers of blast isolates in the 2 pathotypes z00 and z06 therefore differed between groups I and II.

The overall number of pathotypes and the numbers in groups I, IIa, and IIb were 11, 2, 10, and 8, respectively, and the respective diversity indexes were $0.72,0.49,0.75$ and 0.76 . Thus group I had the lowest diversity among the 3 groups, and there was little difference between groups IIa and IIb.

(5) Seven DVs (for Pita-2, Pi12(t), Pita, Pi19(t) and Pi20(t)) in group ta

A total of 26 pathotypes ( $\mathrm{ta} 000, \mathrm{ta} 001, \mathrm{ta} 002, \mathrm{ta} 003$, ta013, ta013, ta020, ta021, ta022, ta023, ta031, ta033, ta113, ta201, ta400, ta401, ta402, ta403, ta412, ta420, ta421, ta422, ta423, ta431, ta602 and ta603) were found against variety group ta (Table 6). The dominant pathotype was ta003 (33 isolates; $27.0 \%): 7(5.7 \%)$ and $25(20.5 \%)$ isolates were included in groups IIa and IIb, respectively, but group I had only 1 isolate. Three pathotypes (ta000, ta002 and ta403) were found only in cluster group II, and 2 pathotypes (ta421 and ta431) occurred only in group I. Thus the virulence genes in 6 pathotypes differed between groups I and II, and the reactions of Pita and Pita-2 were particularly divided according to these groups. Additionally, for pathotypes ta000 and ta002 there were several blast isolates in cluster group IIa, but none in group IIb. The number of isolates of ta003 was higher in group IIb than in group IIa. Thus the reactions of $P i 19(\mathrm{t})$ and $P i 20(\mathrm{t})$ differentiated groups IIa and IIb.

The numbers of pathotypes and diversity index values overall and for groups I, IIa, and IIb were 25 and $0.88,12$ and $0.77,14$ and 0.88 , and 6 and 0.49 , respectively. Thus 
Table 5. Numbers of blast isolates in pathotypes against differential variety group $z$, corresponding to resistance genes $\mathrm{Pi}$ (t), $\mathrm{Piz}, \mathrm{Piz}-5$ and $\mathrm{Piz}-\mathrm{t}$, and the degrees of diversity in cluster groups

\begin{tabular}{|c|c|c|c|c|c|c|c|c|c|c|c|c|c|c|c|}
\hline \multirow{2}{*}{\multicolumn{3}{|c|}{ Cluster group }} & \multicolumn{11}{|c|}{ Number of blast isolates (\%) } & \multirow{6}{*}{ 苞 } & \multirow{6}{*}{ 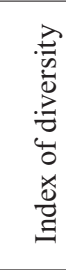 } \\
\hline & & & \multicolumn{11}{|c|}{ Pathotypes } & & \\
\hline \multirow{4}{*}{ 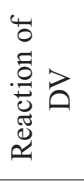 } & \multicolumn{2}{|c|}{ Resistance gene } & $\mathrm{z} 00$ & z01 & z02 & z04 & z05 & z06 & $\mathrm{z} 07$ & $\mathrm{z} 13$ & z14 & z16 & $\mathrm{z} 17$ & & \\
\hline & $P i 9(\mathrm{t})$ & Piz & -- & -+ & -- & -- & -+ & -- & -+ & ++ & +- & +- & ++ & & \\
\hline & - & Piz-5 & - & - & + & - & - & + & + & + & - & + & + & & \\
\hline & - & Piz- $t$ & - & - & - & + & + & + & + & - & + & + & + & & \\
\hline \multicolumn{3}{|c|}{ I } & $\begin{array}{c}0 \\
(0.0)\end{array}$ & $\begin{array}{c}0 \\
(0.0)\end{array}$ & $\begin{array}{c}0 \\
(0.0)\end{array}$ & $\begin{array}{c}22 \\
(18.0)\end{array}$ & $\begin{array}{c}0 \\
(0.0)\end{array}$ & $\begin{array}{c}16 \\
(13.1)\end{array}$ & $\begin{array}{c}0 \\
(0.0)\end{array}$ & $\begin{array}{c}0 \\
(0.0)\end{array}$ & $\begin{array}{c}0 \\
(0.0)\end{array}$ & $\begin{array}{c}0 \\
(0.0)\end{array}$ & $\begin{array}{c}0 \\
(0.0)\end{array}$ & $\begin{array}{c}38 \\
(31.1)\end{array}$ & 0.49 \\
\hline \multicolumn{3}{|c|}{ IIa } & $\begin{array}{c}13 \\
(10.7)\end{array}$ & $\begin{array}{c}2 \\
(1.6)\end{array}$ & $\begin{array}{c}2 \\
(1.6)\end{array}$ & $\begin{array}{c}19 \\
(15.6)\end{array}$ & $\begin{array}{c}2 \\
(1.6)\end{array}$ & $\begin{array}{c}6 \\
(4.9)\end{array}$ & $\begin{array}{c}1 \\
(0.8)\end{array}$ & $\begin{array}{c}1 \\
(0.8)\end{array}$ & $\begin{array}{c}1 \\
(0.8)\end{array}$ & $\begin{array}{c}1 \\
(0.8)\end{array}$ & $\begin{array}{c}0 \\
(0.0)\end{array}$ & $\begin{array}{c}48 \\
(39.3)\end{array}$ & 0.75 \\
\hline \multicolumn{3}{|c|}{ IIb } & $\begin{array}{c}1 \\
(0.8)\end{array}$ & $\begin{array}{c}0 \\
(0.0)\end{array}$ & $\begin{array}{c}0 \\
(0.0)\end{array}$ & $\begin{array}{c}15 \\
(12.3)\end{array}$ & $\begin{array}{c}1 \\
(0.8)\end{array}$ & $\begin{array}{c}4 \\
(3.3)\end{array}$ & $\begin{array}{c}5 \\
(4.1)\end{array}$ & $\begin{array}{c}0 \\
(0.0)\end{array}$ & $\begin{array}{c}4 \\
(3.3)\end{array}$ & $\begin{array}{c}5 \\
(4.1)\end{array}$ & $\begin{array}{c}1 \\
(0.8)\end{array}$ & $\begin{array}{c}36 \\
(29.5)\end{array}$ & 0.76 \\
\hline \multicolumn{3}{|c|}{ Sum } & $\begin{array}{c}14 \\
(11.5)\end{array}$ & $\begin{array}{c}2 \\
(1.6)\end{array}$ & $\begin{array}{c}2 \\
(1.6)\end{array}$ & $\begin{array}{c}34 \\
(27.9)\end{array}$ & $\begin{array}{c}3 \\
(2.5)\end{array}$ & $\begin{array}{c}10 \\
(8.2)\end{array}$ & $\begin{array}{c}6 \\
(4.9) \\
\end{array}$ & $\begin{array}{c}1 \\
(0.8)\end{array}$ & $\begin{array}{c}5 \\
(4.1)\end{array}$ & $\begin{array}{c}6 \\
(4.9)\end{array}$ & $\begin{array}{c}1 \\
(0.8)\end{array}$ & $\begin{array}{c}84 \\
(68.9)\end{array}$ & 0.78 \\
\hline \multicolumn{3}{|c|}{ Total } & $\begin{array}{c}14 \\
(11.5)\end{array}$ & $\begin{array}{c}2 \\
(1.6)\end{array}$ & $\begin{array}{c}2 \\
(1.6)\end{array}$ & $\begin{array}{c}56 \\
(45.9) \\
\end{array}$ & $\begin{array}{c}3 \\
(2.5)\end{array}$ & $\begin{array}{c}26 \\
(21.3) \\
\end{array}$ & $\begin{array}{c}6 \\
(4.9) \\
\end{array}$ & $\begin{array}{c}1 \\
(0.8)\end{array}$ & $\begin{array}{c}5 \\
(4.1) \\
\end{array}$ & $\begin{array}{c}6 \\
(4.9) \\
\end{array}$ & $\begin{array}{c}1 \\
(0.8)\end{array}$ & $\begin{array}{c}122 \\
(100.0)\end{array}$ & 0.72 \\
\hline
\end{tabular}

Each pathotype was categorized in accordance with the method of Hayashi et al. (2009).

- : incompatibility reaction, + : compatibility reaction.

Indexes of diversity were calculated using the method of Simpson (1949).

Table 6. Numbers of blast isolates in pathotypes against differential variety group ta, corresponding to resistance genes Pita2, Pi12(t), Pita, Pi19(t) and Pi20(t), and the degrees of diversity in cluster groups

\begin{tabular}{|c|c|c|c|c|c|c|c|c|c|c|c|c|c|c|c|}
\hline & \multirow{2}{*}{ Cluster group } & \multicolumn{14}{|c|}{ Number of blast isolates (\%) } \\
\hline & & & & & & & & Patho & types & & & & & & \\
\hline \multirow{5}{*}{ 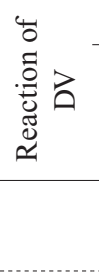 } & Resistance gene & ta000 & ta001 & ta002 & ta003 & ta013 & ta020 & ta 021 & $\operatorname{ta} 022$ & ta023 & ta031 & ta033 & ta113 & ta201 & ta 400 \\
\hline & Pita-2 Pita Pi19(t) & - - - & --+ & -- & --+ & -++ & - - - & $--_{+}$ & -- & --+ & -++ & -++ & +++ & $--_{+}$ & - - - \\
\hline & Pita-2 Pita Pi20(t) & -- & -- & --+ & --+ & --+ & -+ & -+ & -++ & -++ & -+- & -++ & --+ & +-- & -- \\
\hline & $\operatorname{Pi12}(\mathrm{t})$ & - & - & - & - & - & - & - & - & - & - & - & - & - & + \\
\hline & I & $\begin{array}{c}0 \\
(0.0)\end{array}$ & $\begin{array}{c}1 \\
(0.8)\end{array}$ & $\begin{array}{c}0 \\
(0.0)\end{array}$ & $\begin{array}{c}1 \\
(0.8)\end{array}$ & $\begin{array}{c}0 \\
(0.0)\end{array}$ & $\begin{array}{c}0 \\
(0.0)\end{array}$ & $\begin{array}{c}1 \\
(0.8)\end{array}$ & $\begin{array}{c}0 \\
(0.0)\end{array}$ & $\begin{array}{c}1 \\
(0.8)\end{array}$ & $\begin{array}{c}2 \\
(1.6)\end{array}$ & $\begin{array}{c}1 \\
(0.8)\end{array}$ & $\begin{array}{c}0 \\
(0.0)\end{array}$ & $\begin{array}{c}0 \\
(0.0)\end{array}$ & $\begin{array}{c}1 \\
(0.8)\end{array}$ \\
\hline \multirow{3}{*}{ II } & $\mathrm{a}$ & $\begin{array}{c}8 \\
(6.6)\end{array}$ & $\begin{array}{c}3 \\
(2.5)\end{array}$ & $\begin{array}{c}10 \\
(8.2)\end{array}$ & $\begin{array}{c}7 \\
(5.7)\end{array}$ & $\begin{array}{c}0 \\
(0.0)\end{array}$ & $\begin{array}{c}1 \\
(0.8)\end{array}$ & $\begin{array}{c}0 \\
(0.0)\end{array}$ & $\begin{array}{c}4 \\
(3.3)\end{array}$ & $\begin{array}{c}0 \\
(0.0)\end{array}$ & $\begin{array}{c}0 \\
(0.0)\end{array}$ & $\begin{array}{c}0 \\
(0.0)\end{array}$ & $\begin{array}{c}1 \\
(0.8)\end{array}$ & $\begin{array}{c}1 \\
(0.8)\end{array}$ & $\begin{array}{c}0 \\
(0.0)\end{array}$ \\
\hline & $\mathrm{b}$ & $\begin{array}{c}0 \\
(0.0)\end{array}$ & $\begin{array}{c}0 \\
(0.0)\end{array}$ & $\begin{array}{c}0 \\
(0.0)\end{array}$ & $\begin{array}{c}25 \\
(20.5)\end{array}$ & $\begin{array}{c}3 \\
(2.5)\end{array}$ & $\begin{array}{c}0 \\
(0.0)\end{array}$ & $\begin{array}{c}0 \\
(0.0)\end{array}$ & $\begin{array}{c}0 \\
(0.0)\end{array}$ & $\begin{array}{c}1 \\
(0.8)\end{array}$ & $\begin{array}{c}1 \\
(0.8)\end{array}$ & $\begin{array}{c}2 \\
(1.6)\end{array}$ & $\begin{array}{c}0 \\
(0.8)\end{array}$ & $\begin{array}{c}0 \\
(0.0)\end{array}$ & $\begin{array}{c}0 \\
(0.0)\end{array}$ \\
\hline & Sum & $\begin{array}{c}8 \\
(6.6)\end{array}$ & $\begin{array}{c}3 \\
(2.5)\end{array}$ & $\begin{array}{c}10 \\
(8.2)\end{array}$ & $\begin{array}{c}32 \\
(26.2)\end{array}$ & $\begin{array}{c}3 \\
(2.5)\end{array}$ & $\begin{array}{c}1 \\
(0.8)\end{array}$ & $\begin{array}{c}0 \\
(0.0)\end{array}$ & $\begin{array}{c}4 \\
(3.3)\end{array}$ & $\begin{array}{c}1 \\
(0.8)\end{array}$ & $\begin{array}{c}1 \\
(0.8)\end{array}$ & $\begin{array}{c}2 \\
(1.6)\end{array}$ & $\begin{array}{c}1 \\
(0.8)\end{array}$ & $\begin{array}{c}1 \\
(0.8)\end{array}$ & $\begin{array}{c}0 \\
(0.0)\end{array}$ \\
\hline \multicolumn{2}{|r|}{ Total } & $\begin{array}{c}8 \\
(6.6) \\
\end{array}$ & $\begin{array}{c}4 \\
(3.3) \\
\end{array}$ & $\begin{array}{c}10 \\
(8.2) \\
\end{array}$ & $\begin{array}{c}33 \\
(27.0)\end{array}$ & $\begin{array}{c}3 \\
(2.5) \\
\end{array}$ & $\begin{array}{c}1 \\
(0.8) \\
\end{array}$ & $\begin{array}{c}1 \\
(0.8) \\
\end{array}$ & $\begin{array}{c}4 \\
(3.3) \\
\end{array}$ & $\begin{array}{c}2 \\
(1.6) \\
\end{array}$ & $\begin{array}{c}3 \\
(2.5) \\
\end{array}$ & $\begin{array}{c}3 \\
(2.5) \\
\end{array}$ & $\begin{array}{c}1 \\
(0.8) \\
\end{array}$ & $\begin{array}{c}1 \\
(0.8) \\
\end{array}$ & $\begin{array}{c}1 \\
(0.8) \\
\end{array}$ \\
\hline
\end{tabular}

the diversity in group IIb was the lowest, and those in the other groups did not differ greatly.

Based on the method proposed by Hayashi and Fukuta $^{4}$, we characterized 122 blast isolates based on the pathotypes in 5 variety groups. We found 13, 7, 8, 11 and 25 pathotypes in variety groups $\mathrm{U}, \mathrm{i}, \mathrm{k}, \mathrm{z}$ and ta, respectively. Fourteen pathotypes (U63, i0, i7, k000, k100, z00, z04, z06, ta000, ta002, ta003, ta403, ta421 and ta431) had high frequencies and were considered dominant. Of these, 12 (i0, i7, k000, k100, z00, z06, ta000, ta002, ta003, ta403, ta421 and ta431) differed markedly in frequency between cluster groups I and II, while 4 (z00, ta000, ta002 and ta003) differed between subgroups IIa and IIb.

Examination of the numbers of pathotypes and the diversity indexes revealed that cluster group IIa always had the highest values, except when comparing the diversity index value against that of group I in variety group i. The diversity index values of group IIb were always the lowest among the 3 groups, except in the case of group $\mathrm{z}$ in comparison with group IIa. 
(Table 6 continued)

\begin{tabular}{|c|c|c|c|c|c|c|c|c|c|c|c|c|c|c|}
\hline \multirow{2}{*}{\multicolumn{2}{|c|}{ Cluster group }} & \multicolumn{11}{|c|}{ Number of blast isolates (\%) } & \multirow{6}{*}{ 吾 } & \multirow{6}{*}{ 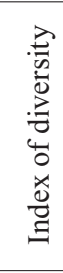 } \\
\hline & & & & & & & athotyp & & & & & & & \\
\hline \multirow{5}{*}{ 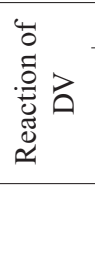 } & Resistance genes & ta401 & ta 402 & ta403 & ta412 & ta 420 & ta421 & ta422 & ta 423 & ta431 & ta602 & ta603 & & \\
\hline & Pita-2 Pita Pi19(t) & --+ & - - - & --+ & -+ & -- & --+ & -- & --+ & -++ & --- & --+ & & \\
\hline & Pita-2 Pita Pi20(t) & $-\cdots$ & --+ & --+ & --+ & -+ & -+- & -++ & -++ & -+- & +-+ & +-+ & & \\
\hline & $\operatorname{Pi12}(\mathrm{t})$ & + & + & + & + & + & + & + & + & + & + & + & & \\
\hline & I & $\begin{array}{c}3 \\
(2.5)\end{array}$ & $\begin{array}{c}0 \\
(0.0)\end{array}$ & $\begin{array}{c}0 \\
(0.0)\end{array}$ & $\begin{array}{c}0 \\
(0.0)\end{array}$ & $\begin{array}{c}1 \\
(0.8)\end{array}$ & $\begin{array}{c}12 \\
(9.8)\end{array}$ & $\begin{array}{c}0 \\
(0.0)\end{array}$ & $\begin{array}{c}1 \\
(0.8)\end{array}$ & $\begin{array}{c}13 \\
(10.7)\end{array}$ & $\begin{array}{c}0 \\
(0.0)\end{array}$ & $\begin{array}{c}0 \\
(0.0)\end{array}$ & $\begin{array}{c}38 \\
(31.1)\end{array}$ & 0.77 \\
\hline \multirow{3}{*}{ II } & a & $\begin{array}{c}0 \\
(0.0)\end{array}$ & $\begin{array}{c}4 \\
(3.3)\end{array}$ & $\begin{array}{c}5 \\
(4.1)\end{array}$ & $\begin{array}{c}1 \\
(0.8)\end{array}$ & $\begin{array}{c}0 \\
(0.0)\end{array}$ & $\begin{array}{c}0 \\
(0.0)\end{array}$ & $\begin{array}{c}1 \\
(0.8)\end{array}$ & $\begin{array}{c}0 \\
(0.0)\end{array}$ & $\begin{array}{c}0 \\
(0.0)\end{array}$ & $\begin{array}{c}1 \\
(0.8)\end{array}$ & $\begin{array}{c}1 \\
(0.8)\end{array}$ & $\begin{array}{c}48 \\
(39.3)\end{array}$ & 0.88 \\
\hline & $\mathrm{b}$ & $\begin{array}{c}0 \\
(0.0)\end{array}$ & $\begin{array}{c}0 \\
(0.0)\end{array}$ & $\begin{array}{c}4 \\
(3.3)\end{array}$ & $\begin{array}{c}0 \\
(0.0)\end{array}$ & $\begin{array}{c}0 \\
(0.0)\end{array}$ & $\begin{array}{c}0 \\
(0.0)\end{array}$ & $\begin{array}{c}0 \\
(0.0)\end{array}$ & $\begin{array}{c}0 \\
(0.0)\end{array}$ & $\begin{array}{c}0 \\
(0.0)\end{array}$ & $\begin{array}{c}0 \\
(0.0)\end{array}$ & $\begin{array}{c}0 \\
(0.0)\end{array}$ & $\begin{array}{c}36 \\
(29.5)\end{array}$ & 0.49 \\
\hline & Sum & $\begin{array}{c}0 \\
(0.0)\end{array}$ & $\begin{array}{c}4 \\
(3.3)\end{array}$ & $\begin{array}{c}9 \\
(9.7)\end{array}$ & $\begin{array}{c}1 \\
(0.8)\end{array}$ & $\begin{array}{c}0 \\
(0.0)\end{array}$ & $\begin{array}{c}0 \\
(0.0)\end{array}$ & $\begin{array}{c}1 \\
(0.8)\end{array}$ & $\begin{array}{c}0 \\
(0.0)\end{array}$ & $\begin{array}{c}0 \\
(0.0)\end{array}$ & $\begin{array}{c}1 \\
(0.8)\end{array}$ & $\begin{array}{c}1 \\
(0.8)\end{array}$ & $\begin{array}{c}84 \\
(68.9)\end{array}$ & 0.81 \\
\hline \multicolumn{2}{|r|}{ Total } & $\begin{array}{c}3 \\
(2.5) \\
\end{array}$ & $\begin{array}{c}4 \\
(3.3) \\
\end{array}$ & $\begin{array}{c}13 \\
(9.7) \\
\end{array}$ & $\begin{array}{c}1 \\
(0.8)\end{array}$ & $\begin{array}{c}1 \\
(0.8) \\
\end{array}$ & $\begin{array}{c}12 \\
(9.8) \\
\end{array}$ & $\begin{array}{c}1 \\
(0.8) \\
\end{array}$ & $\begin{array}{c}1 \\
(0.8) \\
\end{array}$ & $\begin{array}{c}13 \\
(10.7)\end{array}$ & $\begin{array}{c}1 \\
(0.8) \\
\end{array}$ & $\begin{array}{c}1 \\
(0.8) \\
\end{array}$ & $\begin{array}{c}122 \\
(100.0)\end{array}$ & 0.88 \\
\hline
\end{tabular}

Each pathotype was categorized in accordance with the method of Hayashi et al. (2009).

- : incompatibility reaction, + : compatibility reaction.

Indexes of diversity were calculated using the method of Simpson (1949).

\section{Race designation}

In accordance with the methods of Hayashi and Fukuta $^{4}$, the 122 blast isolates were finally categorized into 92 races based on our pathotyping analyses in the 5 variety groups (Table 7).

One blast race, U63-i7-k100-z06-ta431 (group I) was common to 8 isolates, and U63-i0-k000-z04-ta003 (group II) was common to 7 isolates. U63-i0-k000-z07-ta003 (group II) and U63-i0-k000-z14-ta003 (group II) were common to 4 isolates in each. Each of the other blast races was common to only 1 to 3 blast isolates. The 10 blast isolates from wild rice were characterized into 10 different races.

\section{Discussion}

We evaluated a total of 122 blast isolates from Cambodia based on the reaction patterns of 1 susceptible variety, LTH, and of DVs harboring 23 resistance genes (Pish, Pib, Pit, Pia, Pii, Pi3, Pi5(t), Pik-s, Pik-m, Pil, Pik-h, Pik, Pik-p, Pi7(t), Pi9(t), Piz, Piz-5, Piz-t, Pita-2, Pi12(t), Pita, Pi19(t) or Pi20(t)). We found high frequencies of occurrence of virulent blast isolates against 6 DVs (for $P i b$, Pit, Pia, Piz-t, Pi19(t) and Pi20(t)) and of LTH, and low frequencies against $11 \mathrm{DVs}$ (for Pish, Pik-m, Pil, Pik-h, Pik, Pik-p, Pi7(t), Pi9(t), Piz and Pita-2(2)). These findings indicated that blast genes virulent to the resistance genes Pib, Pit, Pia, Piz-t, Pi19(t) and Pi20(t) and avirulent to the resistance genes Pish, Pik-m, Pil, Pik-h, Pik, Pik-p, Pi7(t), $P i 9(\mathrm{t}), P i z$ and Pita-2 in rice were distributed widely among blast fungi in Cambodia.
In accordance with the methods of Hayashi and Fukuta $^{4}$, we classified the blast isolates into 92 races based on the pathotypes of the 5 variety groups. Noda et al. ${ }^{14}$ identified 12 kinds of blast race among 129 isolates collected from all over the Mekong river delta of Vietnam. They used Japanese DVs carrying 12 resistance genes, Pia, Pik-s, Pii, Pik, Pik-m, Piz, Pita, Pita-2, Piz-t, Pik-p, Pib or Pit, selected by Yamada et al. ${ }^{21}$, Kiyosawa ${ }^{8,9}$, and Kiyosawa et al. ${ }^{10}$. Mekwatanakarn et al. ${ }^{13}$ investigated the pathogenicities of 527 blast isolates from Thailand using CO 39 NILs carrying 9 genes (Pi1, Pi1-LAC(t), Pi1-TTP(t), Piz-5, Pi3, Pi4a and Pi4b(t) (Pita), Pi4a-PKT(t), Pi4a-TTP(t) or Pia) and LTH NILs carrying 6 genes (Pik-m, Pita, Pita-2, Pib, Pik- $p$, or $P i k)$; the blast isolates were classified into 175 races. In Bhutan, 110 isolates were differentiated into 53 races based on the reactions of CO 39 NILs carrying Pi4b (Pita), Pi2 (Piz-5), Pi3, Pi4a (Pita), or Pil and LTH NILs carrying Pita, Pib, Pita-2, Pik-m or Pik-p (Thinlay et al. 2000). In China, 792 isolates were classified into 344 races using LTH NILs carrying Pita-2, Pib, Pik, Pik-m, Pita or Pik-p and CO 39 NILs carrying Pita, Piz-5, Pi3 or Pi1 $3^{1}$. The pathogenicities of 119 blast isolates collected from the Philippines were characterized using 19 DVs carrying 18 resistance genes (Pia, Pib, Pii, Pit, Pita, Pish, Piz-t, Pi3, Piz-5, Pik, Pik-h, Pik-m, Pik-p, Pik-s, Pita-2, Piz, Pil or Pi20(t)); the isolates were categorized into 70 races $^{17}$. Many kinds of blast races have thus been found in Bhutan $^{19}$, China ${ }^{1}$, Thailand $^{13}$, and the Philippines ${ }^{17,22}$, but few blast isolates were classified into each race, and no dominant blast races were found. It is difficult to compare our Cambodian data with those from these previous studies, because the numbers 


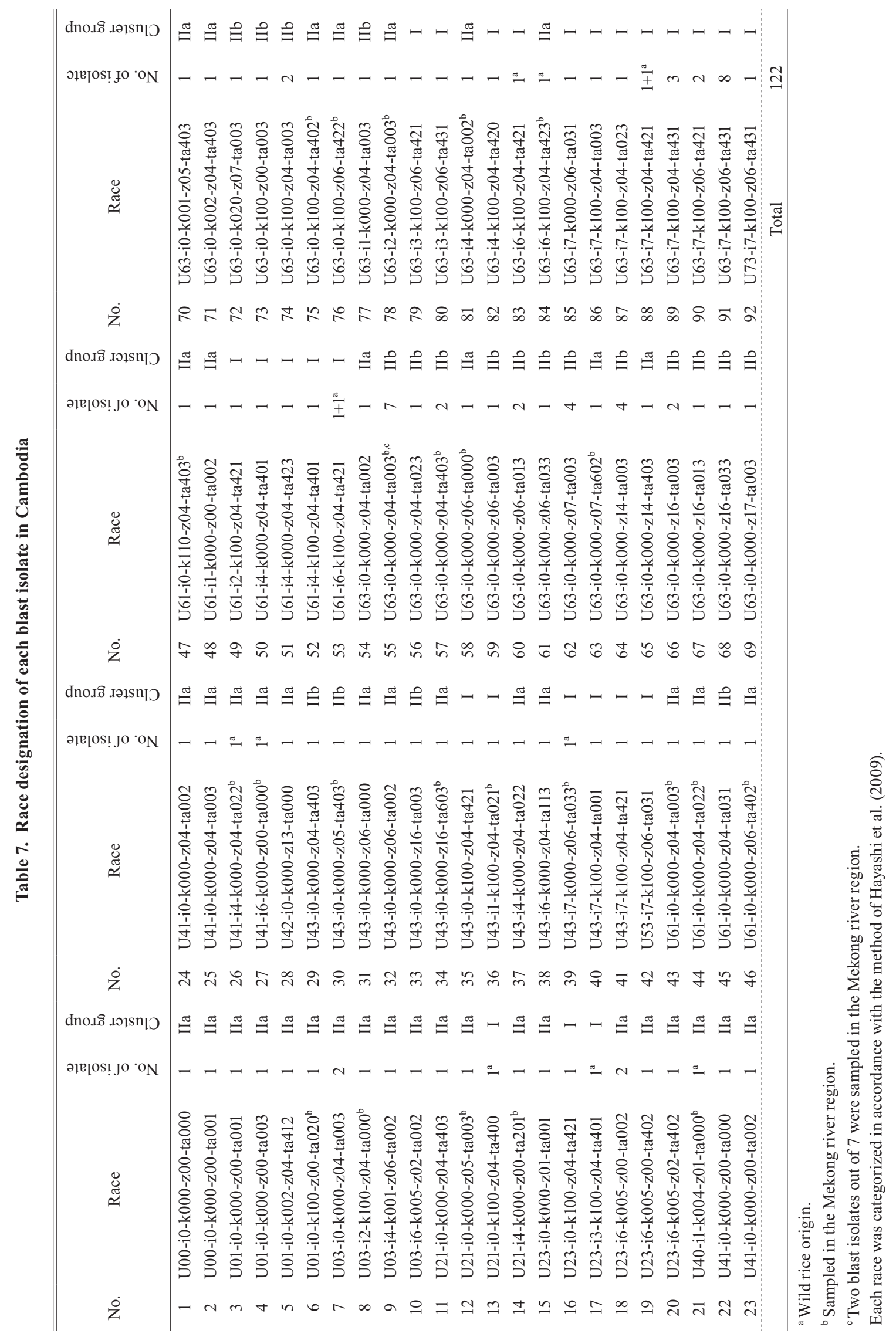


and kinds of resistance genes and genetic backgrounds of the DVs used previously differed from those of monogeneic lines ${ }^{20}$ and NILs ${ }^{18}$. However, as in the other reports, we found numerous races.

The blast isolates were classified into 3 cluster groups, $\mathrm{I}$, IIa, and IIb, based on the reaction patterns of $25 \mathrm{DVs}$ and LTH; 14 pathotypes, namely U63, i0, i7, k000, k100, z00, z04, z06, ta000, ta002, ta003, ta403, ta421 and ta431, were dominant. Of these, 2 pathotypes, U63 and z04, were found in all 3 cluster groups. Thus these 2 pathotypes, U63 and z04, were basically dominant, and 4 blast genes corresponding to the resistance genes Pib, Pit, Pia and Piz-t in rice were distributed together in Cambodia. The other 12 pathotypes, i0, i7, k000, k100, z00, z06, ta000, ta002, ta003, ta403, ta421 and ta431, occurred at different frequencies in cluster groups I and II. The blast races of group I harbored genes at high frequencies for virulence to Pii, Pi3, Pi5(t), Pik-s, Piz-5, Piz-t, Pi12(t) and Pita. In contrast, the races of group II harbored genes at high frequencies for avirulence to Pii, Pi3, Pi5(t), Pik-s, Pi9(t), Piz-5 and Piz-t and for virulence to $P i 19(\mathrm{t})$ and $P i 20(\mathrm{t})$. The 3 pathotypes $\mathrm{z} 00$, ta002 and ta003, for avirulence genes of variety groups $\mathrm{z}$ and ta except for DV of Pi19(t), divided between subgroups IIa and IIb as additional factors. In other words, the presence or absence of the 12 pathotypes i0, i7, k000, k100, z00, z06, ta000, ta002, ta003, ta403, ta421 and ta431 plays a major role in differentiating blast races in Cambodia.

Blast isolates of groups I, IIa and IIb were distributed with similar frequencies in the Tonle Sap region, whereas group IIa was found at high frequency, and groups I and IIb at low frequency, in the Mekong river region. In terms of race, a comparison of the blast isolates in group IIa between the 2 regions revealed that the 6 found only in the Mekong river region were of pathotype $\mathrm{k} 100$ or $\mathrm{k} 110$. Thus the distributions of blast races differed between the Tonle Sap and Mekong river regions; notably, the blast isolates from the Mekong river tended to be virulent against the resistance gene Pik-s in variety group k. Examination of the numbers of pathotypes and diversity index values of the blast isolates indicated that cluster group IIa always had the highest values, except in the case of the diversity index values in variety group $\mathrm{z}$. The numbers of pathotypes and diversity index values in group IIb were always the lowest among the 3 groups except for group z, although there was little difference in diversity index values between group IIa and IIb in group z. Among the 3 blast isolate groups, group IIa, which included genes at low frequencies for virulence to Pib, Pit, Pia, Piz-5, Piz- $t$ and Pi19(t) and maintained a high degree of diversity, was distributed commonly in all regions. Additionally, groups I and IIb, which included several dominant pathotypes, were distributed in the Tonle Sap region.
In other words, group IIa represented the basic population of blast races in Cambodia, and groups I and IIb were modified from IIa in accordance with rice cultivation conditions in the Tonle Sap region. These unique distributions of blast races among 3 regions might occur and be attributable to differences in genotypes of blast resistance genes in rice varieties cultivated based on the gene-for-gene theory ${ }^{2,15}$. It will be necessary to clarify the genotypes of rice varieties in each region of Cambodia and the relationship between blast races and rice varieties.

A total of 10 blast isolates from wild rice (O. rufipogon) were collected and analyzed for pathogenicity. These blast isolates were categorized into groups I (6 isolates) and IIa (4 isolates) and were not found in group IIb. In the Tonle Sap region, the 5 blast isolates were found only in group I. In the Mekong river region, 1 isolate occurred in group I and 4 in group IIa; their distributions might correspond to the distributions of isolates on cultivated rice in this region. These results suggested that the blast races on wild rice were differentiated according to the pathotypes of those on cultivated rice. Many more samples of blast fungus are needed to clarify the distributions of the dominant blast races in detail and the relationship between those on cultivated and wild rice respectively.

Although the blast isolates used were limited, our results are a clear first step in elucidating the diversity and differentiation of blast races in Cambodia using monogeneic lines $^{20,6}$ and LTH NILs ${ }^{18}$ as DVs, along with the designation system proposed by Hayashi and Fukuta ${ }^{4}$. This information will be used to select standard differential blast isolates and develop a differential system with increasing numbers of blast isolates. It will also facilitate detailed analyses of pathogenicity. By developing and applying this differential system, the pathogenicity of blast isolates and the genotypes of resistance genes in rice varieties will be enhanced in breeding and pathological studies, enabling a system of durable blast protection to be built up in Cambodia. Information on blast races in neighboring countries such as Vietnam, Laos, Thailand, and China will be also needed if we are to understand the distribution, differentiation, and influence of races and develop future protection systems. To enhance these studies, the development of common materials, methods, and tools, such as monogeneic lines ${ }^{20}$ and LTH NILs ${ }^{18}$, along with a scoring system and designation system ${ }^{4,5}$, will be useful. An international collaborative study, "Blast Research Network for Stable Rice Production," is underway and will help clarify the diversity of blast races, distribute the differential system, and establish a system to protect against blast disease on a global scale. These Cambodian data will be evaluated and compared with international information as part of this collaborative research. 


\section{References}

1. Chen, H. et. al (2001) Pathotypes of Pyricularia grisea in rice fields of central and southern China. Plant Dis., 85, 843850.

2. Flor, H. H. (1971) Current status of gene-for-gene concept. Adv. Genet., 8, 29-54.

3. Gilmour, J. (1973) Octal notation for designating physiologic races of plant pathogens. Nature, 242, 620.

4. Hayashi, N. \& Fukuta, Y. (2009) Proposal for a new international system of differentiating races of blast (Pyricularia oryzae Cavara) using LTH monogenic lines in rice (Oryza sativa L.). JIRCAS working report No. 63. Tsukuba city, Ibaraki prefecture, Japan, Japan International Research Center for Agricultural Sciences, 11-15.

5. Hayashi, N. et al. (2009) Protocols for the sampling of diseased specimens and evaluation of blast disease in rice. JIRCAS Working Report No. 63. Tsukuba city, Ibaraki prefecture, Japan, Japan International Research Center for Agricultural Sciences, 17-33.

6. Kobayashi, N. et al. (2007) Development of new sets of international standard differential varieties for blast resistance in rice (Oryza sativa L.). JARQ, 41, 31-37.

7. Koizumi, S. (2007) Durability of resistance to rice blast disease. In A Differential System for Blast resistance for Stable Rice Production Environment. JIRCAS Working Report No. 53, eds. Fukuta, Y. et al., Tsukuba, Japan, 1-10.

8. Kiyosawa, S. (1971) Gene analysis of blast resistance in exotic varieties of rice. JARQ, 6, 8-15.

9. Kiyosawa, S. (1984) Establishment of differential varieties for pathogenicity test of rice blast fungus. Rice Genet. Newsl., 1, 95-96.

10. Kiyosawa, S. et al. (1981) Pathogenicity tests of Philippine isolates of blast fungus using two sets of rice varieties. Jpn. J. Breed., 31, 367-376.

11. Ling, Z. et al. (1995) Development of near-isogenic lines as international differentials of the blast pathogen. Int. Rice Res.
Notes, 20, 13-14.

12. Mackill, D. J. \& J. M. Bonman (1992) Inheritance of blast resistance in near-isogenic lines of rice. Phytopathol., 82, 746-749.

13. Mekwatanakarn, P. et al. (2000) Pathotype and avirulence gene diversity of Pyricularia grisea in Thailand as determined by rice near-isogenic lines for major resistance genes. Plant Dis., 84, 60-70.

14. Noda, T. et al. (1999) Distribution of pathogenic races of rice blast fungus in Vietnam. Ann. Phytopathol. Soc. Jpn., 65, 526-530.

15. Silue, D.et al. (1992) Evidence for a gene for gene relationship in the Oryza sativa - Magnaporthe grisea pathosystem. Phytopathol., 82, 577-580.

16. Simpson E. H. (1949) Measurement of diversity. Nature, 163, 688.

17. Telebanco-Yanoria, M. J. et al. (2008) A set of standard differential blast isolates (Magnaporthe grisea (Hebert) Barr.) from the Philippines for rice (Oryza sativa L.) resistance. $J A R Q, 42,23-34$.

18. Telebanco-Yanoria, M. J. et al. (2010) Development of nearisogenic lines of Japonica-type rice variety Lijiangxintuanheigu as differentials for blast resistance. Breed. Sci., 60, 629-638.

19. Thinlay, R. et al. (2000) Pathogenic variability of Pyricularia grisea from the high- and mid-elevation zones of Bhutan. Phytopathol., 90, 621-628.

20. Tsunematsu, H. et al. (2000) Development of monogenic lines for rice blast resistance. Breed. Sci., 50, 229-234.

21. Yamada, M. et al. (1976) Proposal of a new method of differentiating races of Pyricularia oryzae Cavara in Japan. Ann. Phytopathol. Soc. Jpn., 42, 216-219.

22. Zeigler, R. et al. (1994) Linking blast population to resistance breeding: A proposed strategy for durable resistance. In Rice Blast Disease, eds. Zeigler, R. S. et al., CAB International, Wallingford, UK, 267-292. 